\title{
Folate deficiency and congenital malformations induced by pyrimethamine in the rat
}

\author{
F Raynaud, C Horvàth \\ Laboratoire de Physiopathologie du Développement, Université Pierre-et-Marie-Curie, Boîte 27, \\ 4, place Jussieu, 75252 Paris cedex 05, France
}

(Received 13 December 1993; accepted 18 July 1994)

\begin{abstract}
Summary - In order to establish a relationship between the appearance of congenital malformations and the decrease of folic acid in rat mothers and embryos, a folic acid antagonist, pyrimethamine (PY), was administered. On the 12th day of gestation/pregnant rats received an intraperitoneal injection of $12.5,15.63,18.75$ or $25 \mathrm{mg} / \mathrm{kg}$ PY. On the 13th day of gestation folic acid was measured in different maternal and embryonic tissues obtained after surgical hysterectomy of 1 uterine horn. On the 21 st day of gestation malformations were studied on live fetuses remaining in the opposite horn. The folate levels were identical in all maternal tissues. The concentration of folic acid significantly decreased $(50 \%)$ within the embryonic tissues in all PY-treated groups. A decrease of fetal weight occurred in the 18.75 and $25 \mathrm{mg} / \mathrm{kg}$ PY groups. Malformations were observed in the same groups. A dysfunction of the placental transfer of folates is hypothesized.
\end{abstract}

folate deficiency / pyrimethamine / development / rat

Résumé - Carence folique et malformations congénitales induites par la pyriméthamine chez le rat. Afin d'établir une relation entre l'apparition des malformations congénitales et la chute d'acide folique, un médicament antifolique, la pyriméthamine ( $P Y)$, a été injecté (ip) à des rates au $12^{\circ}$ jour de gestation. Au $13^{\circ}$ jour de gestation, on ne note aucune différence dans les taux d'acide folique du sang total, du plasma et du foie des mères traitées aux 4 doses utilisées : 12,$5 ; 15,63 ; 18,75$ et $25 \mathrm{mg} / \mathrm{kg}$ de $P Y$ par rapport aux rates témoins. Dans les tissus embryonnaires (têtes, corps et placentas embryonnaires) la concentration des folates diminue de façon hautement significative dès la plus faible dose (12,5 $\mathrm{mg} / \mathrm{kg}$ ). Au $21^{e}$ jour de gestation, un seul foetus $(12,5 \mathrm{mg} / \mathrm{kg})$ est malformé et les poids fotaux restent identiques à ceux des témoins aux doses de 12,5 et 15,63 mg/kg PY. Avec les doses de 18,75 et 25 $\mathrm{mg} / \mathrm{kg}$ de $P Y$, le nombre de foetus malformés (anomalies de la face, des membres et des viscères) augmente significativement et les poids foetaux diminuent simultanément très significativement. Le rôle de la fonction placentaire est discuté.

carence folique / pyriméthamine / développement / rat 


\section{INTRODUCTION}

Folates play an important role in organogenesis. As early as 1950, Thiersch and Philips showed that injection of the folic acid antagonist, aminopterin, to pregnant rats and mice resulted in fetal death and resorption. Consequently, this folic acid antagonist was used as a human abortifacient. The administration of the drug to women less than 3 months pregnant (Thiersch, 1952) induced fetal death followed by abortion (10/12 cases) and congenital malformations (hydrocephalus, cleft lip and palate) (2 remaining cases). Folic acid deficiency, either due to malnutrition (Laurence et al, 1980 ) or artificially induced by a poor maternal diet (Baird et al, 1954; Monie et al, 1954; Monie et al, 1957), is teratogenic.

A great number of drugs are folic acid antagonists, such as methotrexate, anticonvulsants and antimalarial agents, and induce congenital malformations (Milunski et al, 1968; Powel and Ekert, 1971; Hill et al, 1974; Hanson and Smith, 1975; Jordan et al, 1977; Warkany, 1978; Wilson et al, 1979). Pyrimethamine, an antimalarial drug, is highly teratogenic in the rat (Dyban et al, 1976; Sullivan and McElhatton, 1977; Tangapregassom et al, 1985; Horvath et al, 1989; Raynaud et al, 1990).

The purpose of the present investigation was to establish a relationship between the appearance of congenital malformations and the decrease of folic acid within different maternal and embryonic tissues induced by various doses of pyrimethamine (PY).

\section{MATERIALS AND METHODS}

\section{Animals}

Virgin Wistar rats, SPF (Centre d'Élevage R Janvier, route des Chênes-Secs, BP 5, 53940 Le
Genest-Saint-Isle, France), kept under the same environmental conditions $\left(23^{\circ} \mathrm{C}, 14 \mathrm{~h} / 10 \mathrm{~h}\right.$ light/dark cycle) were used. The females were housed (in groups of 5) in plastic cages with stainless-steel wire lids on sawdust bedding. Males were caged per groups of 2 or 3 in the same room. All animals were fed on a standard diet (A O3, UAR, France). Food and tap water were provided ad libitum.

Females weighing 180-200 g were mated overnight with a potent male of the same strain. The male was introduced in the female's cage in the evening $(6 \mathrm{pm})$. The next morning, detection of spermatozoa in the vaginal smear was considered as day 1 of pregnancy. Pregnant females were then housed in individual cages until term.

\section{Treatment}

On the 12th day of gestation $(5 \mathrm{pm})$ the treated females received an intraperitoneal injection of $12.5,15.63,18.75$ or $25 \mathrm{mg} / \mathrm{kg}$ PY (RhônePoulenc Specia, Paris, France) in $2 \mathrm{ml}$ saline $(\mathrm{NaCl} 0.9 \%)$. Control rats received vehicle only.

A dose of $25 \mathrm{mg} / \mathrm{kg} P Y$ is highly teratogenic in the rat (Compagnon, 1987; Raynaud et al, 1990). Starting with this dose the dosages were reduced in a mathematical order.

\section{Sampling methods}

\section{Experimental conditions}

Folic acid was assayed on various maternal and embryonic tissues on the 13th day of gestation, and fetal malformations were studied on the 21st day. Each female was her own control.

\section{Sampling for folic acid assay}

The females were operated between 9 and 11 am under general ether anaesthesia with strict asepsis. Maternal blood samples were drawn by cardiac puncture into heparinized tubes. A hemihysterectomy was performed by laparotomy on all gravid uteri after ligature of the utero-tubal and utero-vaginal junctions. A liver fragment was then immediately ligated and withdrawn. Muscular and cutaneous walls were sutured and the mothers 
replaced in their cages. Postoperative care was given to the animals until term.

As they were obtained, the different samples were kept in crushed ice until the end of the operation. The maternal (blood and liver) and embryonic (heads, bodies and embryonic placentas) samples were treated according to Raynaud et al, 1990.

\section{Folic acid assay method}

Folic acid was assayed as mono- or oligoglutamate residues by a bacteriological method (Bird et al, 1965; Christidès and Potier de Courcy, 1987) utilizing Lactobacillus rhamnosus. The values of the standard curve extend between 50 and $1000 \mathrm{ng}$. Results are expressed as $\mathrm{ng} / \mathrm{ml}$ for maternal blood and plasma, ng/mg for embryonic tissues and $\mu \mathrm{g} / \mathrm{mg}$ for maternal live.

\section{Sampling for fetal malformations studies}

On gestation-day 21 , the autopsy of the females was carried out after an ether overdose and the remaining pregnant uterine horn was examined. The number of early and late resorptions and their location were noted. The number of live and dead fetuses was recorded. Live fetuses were removed, weighed and examined for external anomalies.

The fetuses were randomly divided into 2 groups. In the first group the fetuses were fixed in $96 \%$ ethanol, then stained with alizarin red $\mathrm{S}$ and alcian blue (Peters, 1977, modified by Honvàth) in order to study skeletal malformations. The fetuses assigned to the second group were fixed in Bouin's fluid and later dissected to allow the study of visceral malformations (Wilson, 1965).

\section{Statistical analysis}

All data are presented as means with their standard error (SEM). Analysis of variance (Anova) and the Kurskal-Wallis test were used to evaluate the effect of the different doses of $P Y$ on folic acid. The action of this drug on teratogenesis was analyzed by Anova (fetal weight) and $\mathrm{chi}^{2}$ (malformations). The 0.05 level of significance was chosen for all studies.
In order to study the relationship between the individual fetal weight and the degree of malformations we used the sunflowers symbols. Each sunflowers shows the number of observations: a dot means 1 observation, a dot with 1 line means 2 observations, a dot with 2 lines means 3 observations, a dot with 3 line segments means 4 observations and so on (Chambers et al, 1983).

\section{RESULTS}

\section{Effects of pyrimethamine on folic acid}

No significant difference between the values of folic acid in maternal tissues was registered after injection of the 4 doses of PY compared to control rats (fig 1). In embryonic tissues (heads, bodies and embryonic placentas) folate levels decreased by approximately $50 \%$ with the lowest dose of PY (12.5 mg/kg; fig 2). Administration of higher doses $(15.63,18.75$ or $25 \mathrm{mg} / \mathrm{kg}$ ) had no additional effect.

The difference between the 4 treated and the control groups was highly significant but there was no difference between the treated groups, except for the embryonic bodies, where the concentrations were on the threshold of significance.

\section{Effects of pyrimethamine on gestation}

Mean fetal weight was not statistically different for the 12.5 and $15.63 \mathrm{mg} / \mathrm{kg} P Y$ treated groups when compared with the control group $(3.75 \pm 0.39 \mathrm{~g}, 3.49 \pm 0.38 \mathrm{~g}$ and $3.83 \pm 0.38 \mathrm{~g}$, respectively) (fig 3 ).

Decrease of fetal weight was highly significant after administration of the 2 highest doses (18.75 and $25 \mathrm{mg} / \mathrm{kg} P Y$ ), being $3.07 \pm 0.59 \mathrm{~g}$ and $2.85 \pm 0.73 \mathrm{~g}$, respectively. No significant difference in fetal weights was found between the 2 highest doses. Of the 111 fetuses examined in the 

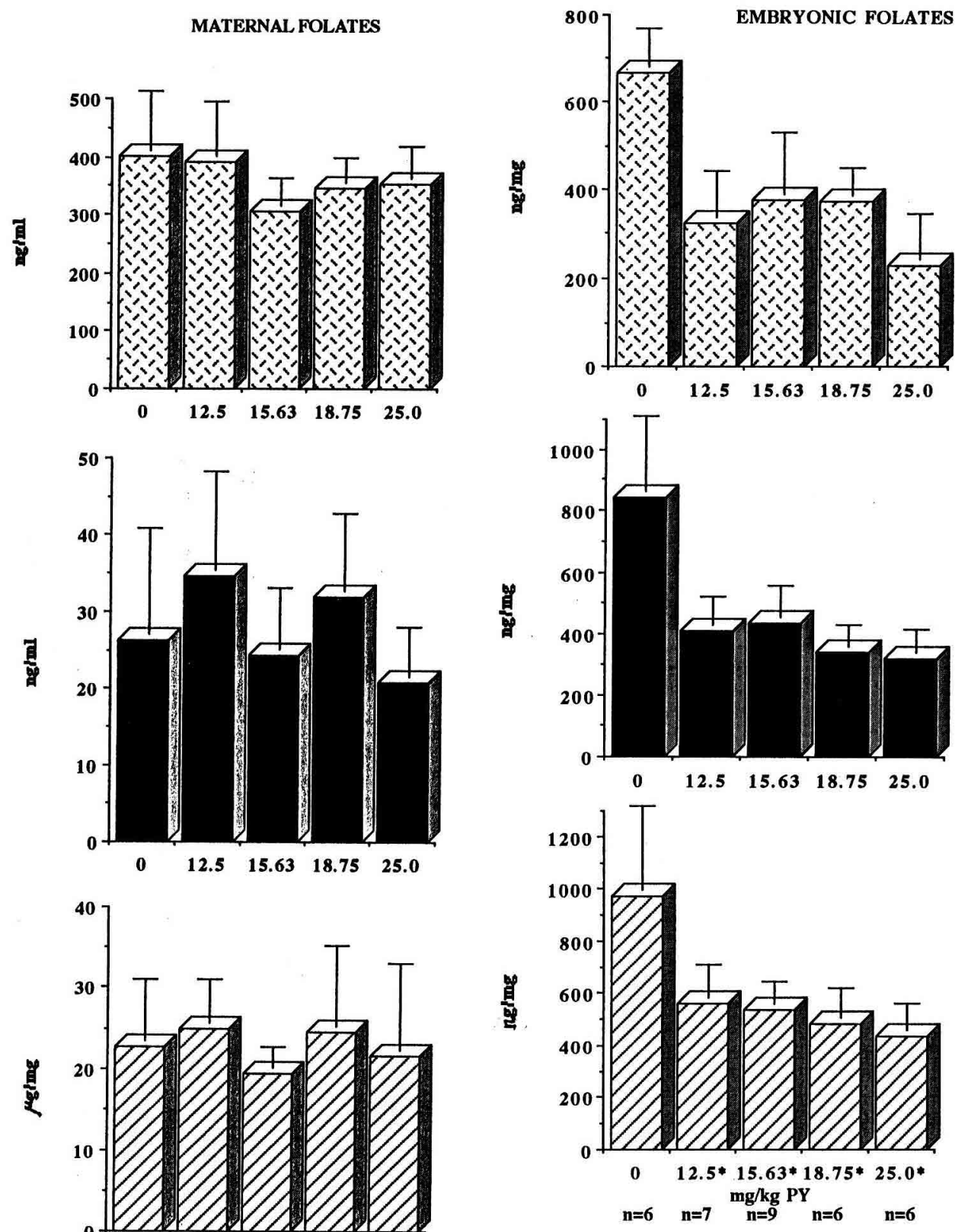

Fig 2. Effect of various doses of PY on mean $( \pm$ SEM) folic acid concentrations on embryonic tissues (top: heads, middle: bodies; bottom: placentas) on the 13 th day of gestation. Stars indicate a highly significant difference compared with the control group (0). PY was injected to pregnant rats on gestation day 12 in the evening (5 pm).

Fig 1. Effect of various doses of $P Y$ on mean ( \pm SEM) folic acid concentrations on maternal tissues (top: blood; middle: plasma; bottom: liver) on the 13th day of gestation. 


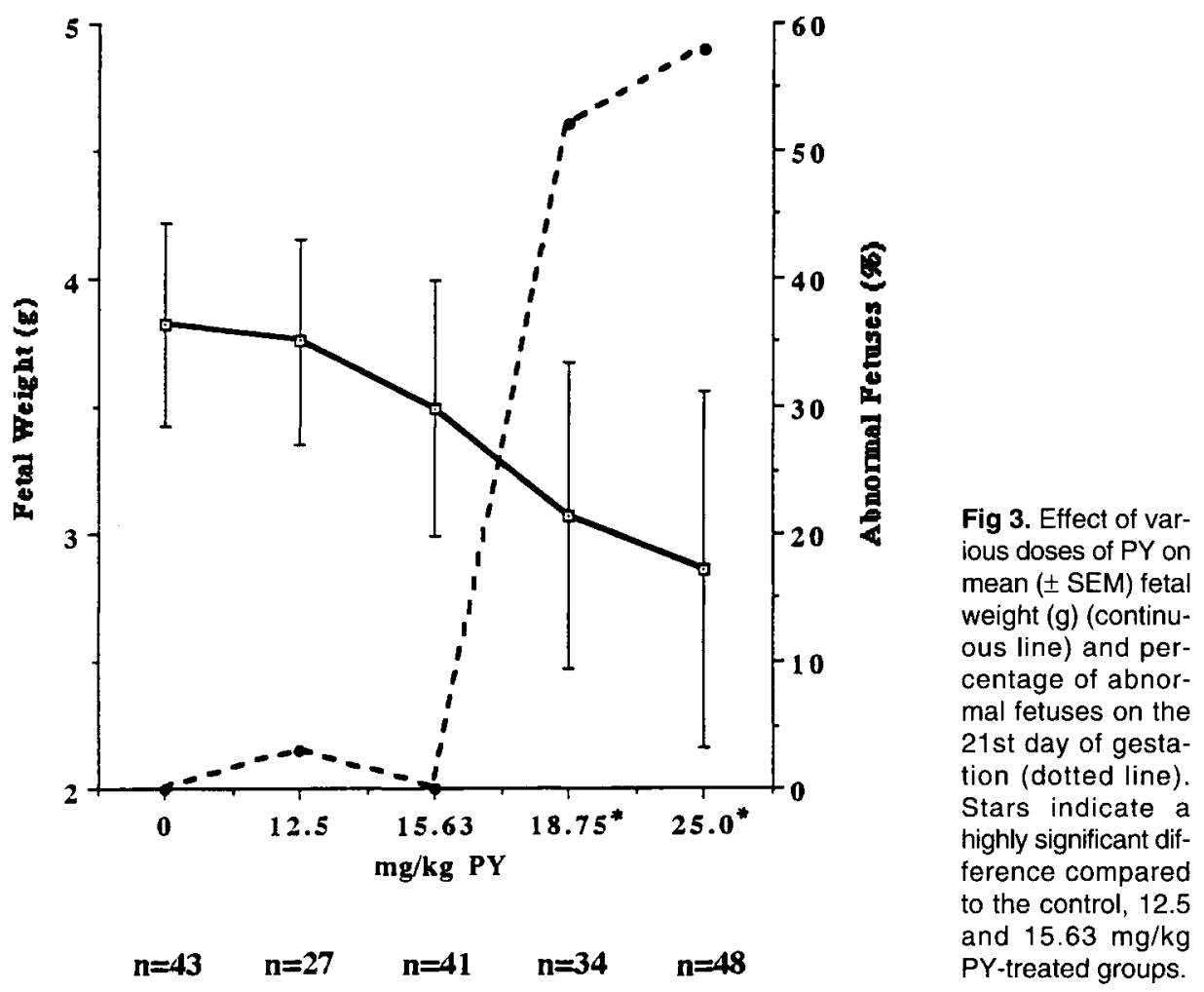

Table I. Scale of seriousness of the various malformations observed on the 21 st day of gestation.

No malformation

$1 \quad$ Light micrognathia

$2 \quad$ Micrognathia + short and kinky tail

3 Palatoschisis or micrognathia + palatoschisis

$4 \quad$ Palatoschisis + malformed tail

5 Micrognathia + palatoschisis + malformed tail

6 Micrognathia + limb malformations or palatoschisis + limb malformations or malformed limbs only

$7 \quad$ Micrognathia + palatoschisis + malformed limbs

8 Micrognathia + palatoschisis + malformed limbs + malformed tail

9 Micrognathia + palatoschisis + malformed limbs + malformed tail + various visceral malformations 


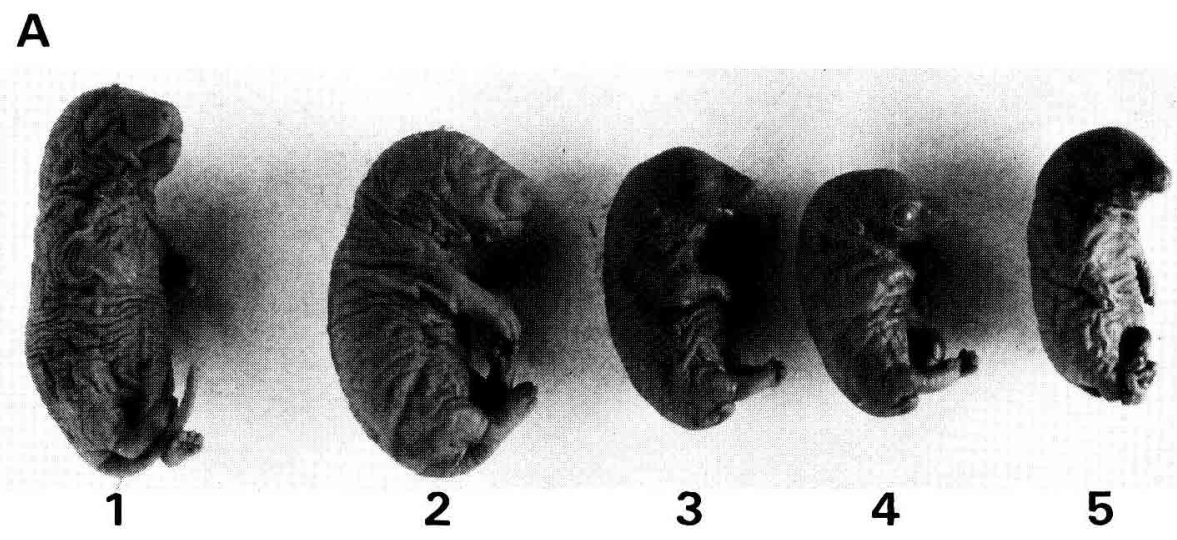

B

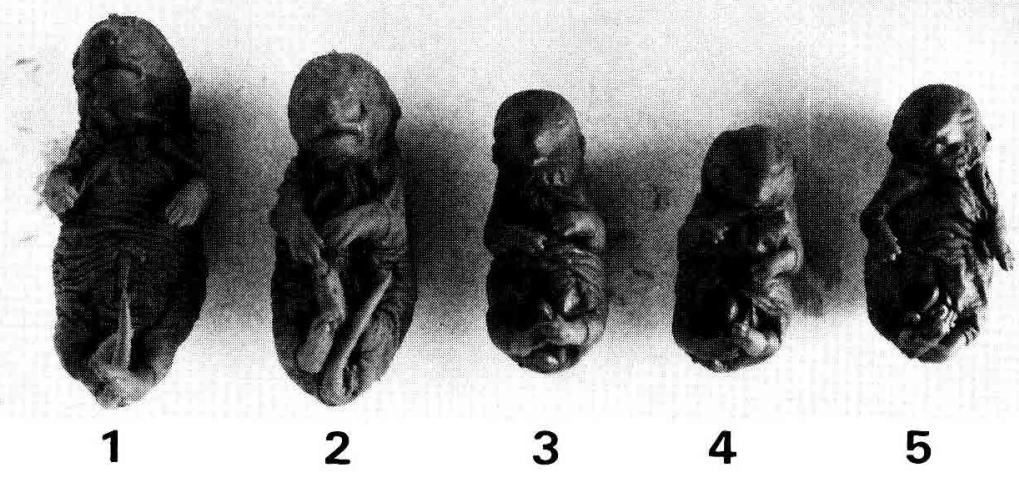

C
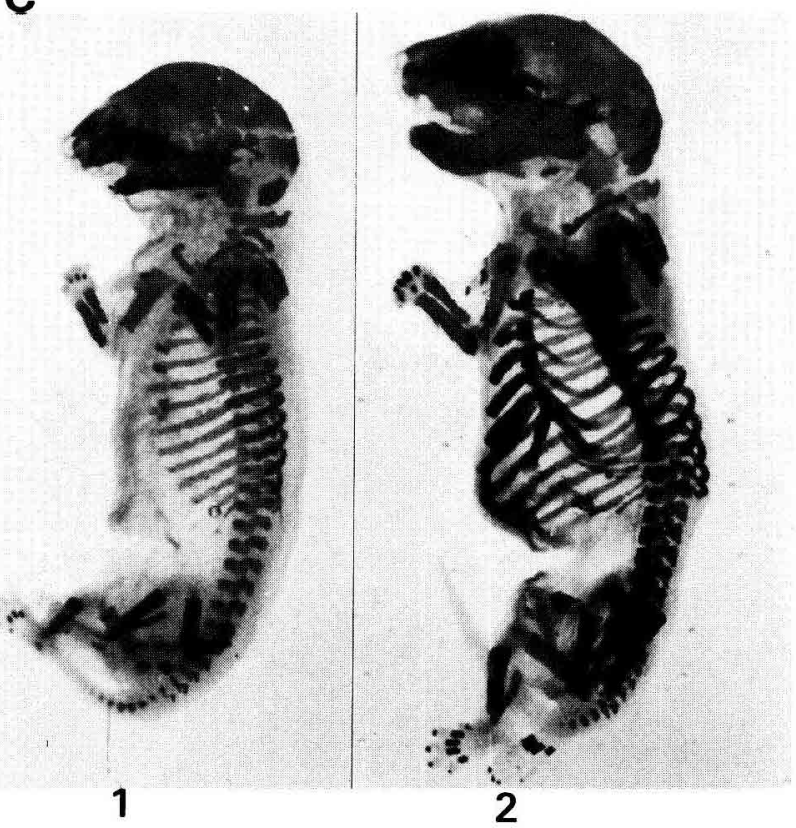
first 3 groups (control, 12.5 and $15.63 \mathrm{mg} / \mathrm{kg}$ $\mathrm{PY}$ ), only one, originating from the 12.5 $\mathrm{mg} / \mathrm{kg}$ PY-treated group, showed slight malformations. After injection of 18.75 and 25 $\mathrm{mg} / \mathrm{kg}$ PY to the mothers, the number of malformed fetuses significantly increased, reaching 52.9 and $58.3 \%$ for 18.75 and 25 $\mathrm{mg} / \mathrm{kg}$ PY groups, respectively. Severe malformations were observed: agnathia, micrognathia, palatoschisis, adactylia, syndactylia, micromelia, tail agenesia, short and kinky tail, anophtalmia, open eyes, urogenital malformations and coelosomia (fig 4).

Several fetuses were polymalformed to such a degree that we decided to establish a scale of seriousness of the malformations (0 to 9 ; table 1).

Figure 5 shows the relationship between the toxic or teratogenic effect and the fetal individual weight. Independently of the dose administered, no malformed fetus was observed for a fetal weight over $3 \mathrm{~g}$. All control fetuses as well as all the fetuses except 1 from the $12.5 \mathrm{mg} / \mathrm{kg}$ PY-treated mothers weighed more than $3 \mathrm{~g}$. A toxic but not teratogenic effect of the drug was noted for normal fetuses weighing less than $3 \mathrm{~g}$. The limit between the toxic and the teratogenic effect clearly appears with the 2 highest doses ( 18.75 and $25 \mathrm{mg} / \mathrm{kg}$ PY). Malformations at the 9 th grade of the scale were observed in one case (18.75 mg/kg PY) and 9 cases (25 mg/kg PY). At the same time the number of malformed fetuses increased in these 2 groups.

Detachment of embryonic maternal placentas was particularly easy in most of the 18.75 and $25 \mathrm{mg} / \mathrm{kg}$ PY-treated mothers. Important degenerative placental changes (necrosis, vascular lesions) were also observed in the same groups at term.

\section{DISCUSSION}

Folates play a basic role in the transfer of single carbon units for the synthesis of 3 bases (adenine, guanine and thymidine) constituting the DNA molecule and some amino acids, such as glycine, purine, methionine and histidine, thus forming key molecules of nucleic acid synthesis and consequently mitosis. PY inhibits the enzyme dihydrofolate reductase, stops the folate cycle, then abolishes tetrahydrofolates synthesis. Cell divisions are disturbed resulting in abnormal organogenesis (fig 6).

Our results clearly demonstrate that the folic acid levels were identical for the various experimental and control maternal tissues whereas a highly significant decrease was noted in embryonic tissues as soon as the lowest dose of PY $(12.5 \mathrm{mg} / \mathrm{kg})$ was applied. These results seem to be in contradiction with the assertion that the only source of folic acid for the embryo is of maternal origin (Potier de Courcy and Bertaux, 1972; Potier de Courcy and Bujoli, 1981). All samples were taken approximately $18 \mathrm{~h}$ after the drug injection. PY half-life is $8 \mathrm{~h}$ in the rat (Compagnon, 1987). The drug was probably eliminated from the maternal organism when sampling took place and it is more likely that the mothers' folates store was rebuilt up at that time while the embryo's supply would not be restored since the transfer of folates from the mother to the embryo requires $24 \mathrm{~h}$ (Landon et al, 1975).

Fig 4. External, skeletal and visceral malformations observed on 21-day-old rat fetuses after administration of various doses of PY to the mothers on the 12th day of gestation. $\mathbf{A}$ and $\mathbf{B}$ : fetuses fixed in Bouin's fluid. A: side view; B: front view of the same fetuses (real size). 1 and 2: normal fetuses (1: control; 2: $15.63 \mathrm{mg} / \mathrm{kg}$ PY); 3-5: abnormal fetuses (3: $18.75 \mathrm{mg} / \mathrm{kg} ; 4$ and 5: $25 \mathrm{mg} / \mathrm{kg}$ PY) showing various malformations: micrognathia, syndactylia, short and kinky tail (3); open eyes, agnathia, syndactylia, coeIosomia (4); agnathia, anophtalmia, syndactylia, cœlosomia, micromelia and tail agenesia (5). C: skeletons (in toto staining $\times 3$ ). $1: 25 \mathrm{mg} / \mathrm{kg}$ PY, micrognathia, short tail, forelimbs adactylia; 2 : normal control. 


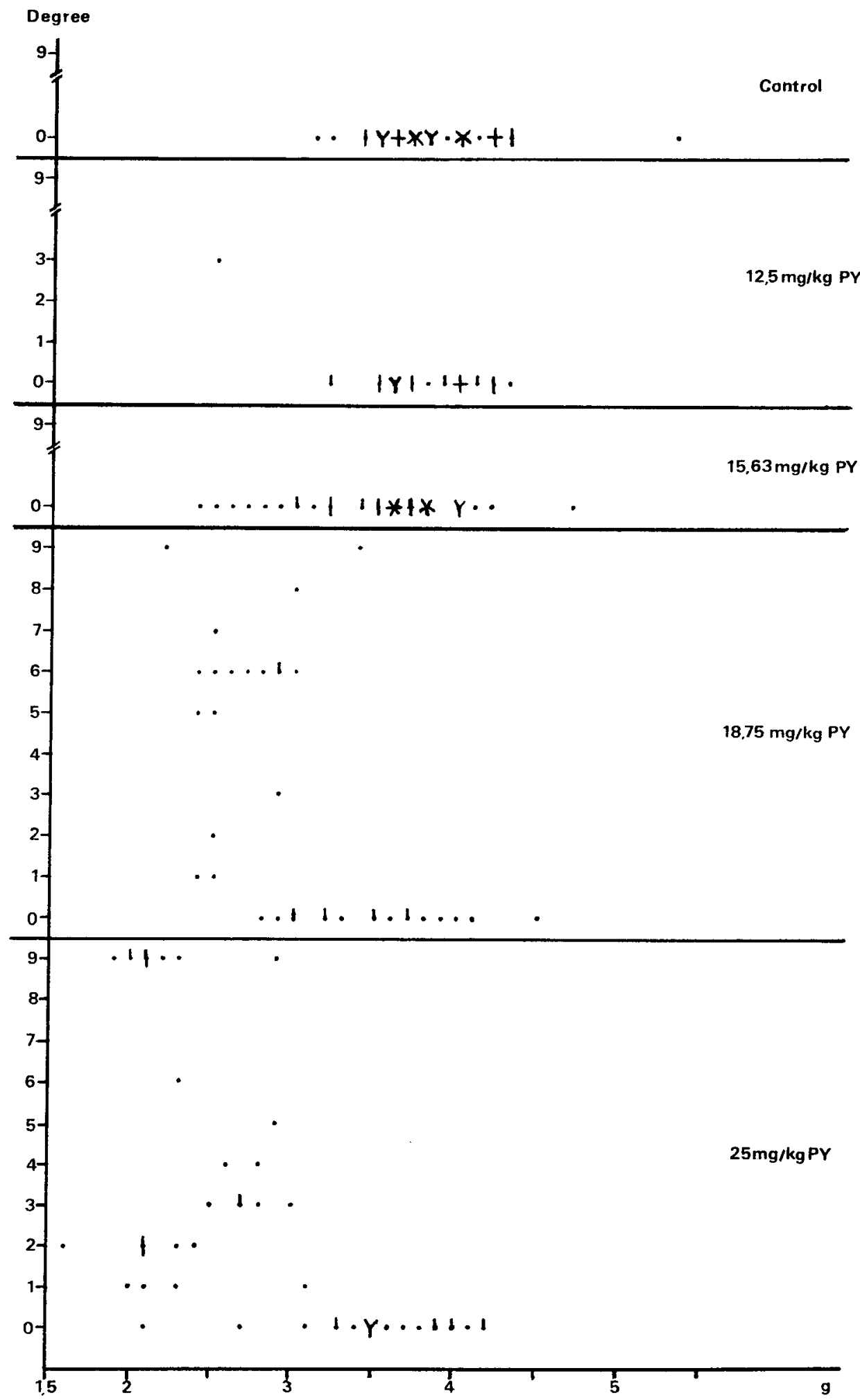

Fig 5. Relationship between the toxic or teratogenic effect and the individual fetal weight. See text for explanation of sunflowers symbols. 


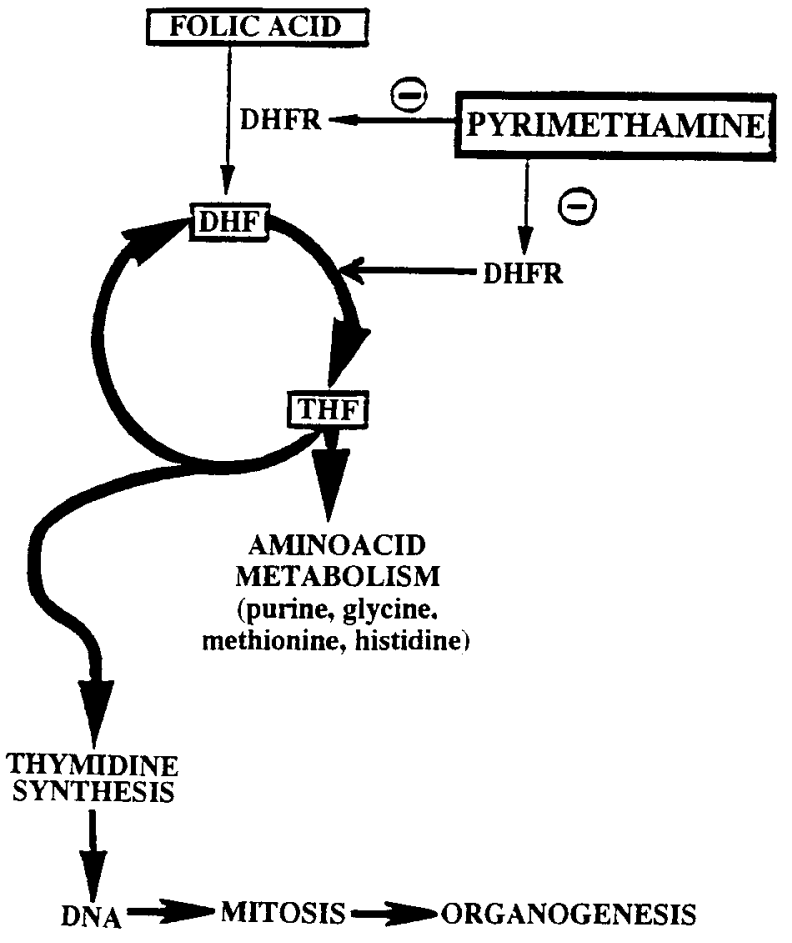

DHF : Dihydrofolic acid

THF : Tetrahydofolic acid

DHFR : Dihydrofolic acid reductase

Fig 6. Role of folic acid in organogenesis. Folic acid and its biologically active derivatives, dihydrofolic acid (DHF) and tetrahydrofolic acid (THF), are involved in DNA synthesis and amino-acid metabolism. Pyrimethamine, a dihydrofolate reductase (DHFR) inhibitor, prevents DNA synthesis, thus leading to abnormal organogenesis.

The placental membrane is directly involved in the transfer of folates from the mother to the fetus. Very little information is available regarding this transfer. The existence of a folate (pteroyl-glutamic) binding protein (FABP) has been demonstrated in human (Green and Ford, 1984) and guinea-pig (Sweiry and Yudilevitch, 1985) trophoblast microvilli. Landon et al (1975) found a higher concentration of folates in the fetal circulation than in the maternal cir- culation and inferred that active transport processes are involved.

The degenerative placental changes observed are in good agreement with the histological studies of Johnson et al (1963). Using 9-methyl-PGA, these authors found slight hemorrhages and vacuolization and pyknosis of giant cells at the maternal-fetal junction in rats. Similar placental and teratogenic effects were obtained by Khera (1992) after administration of valproic acid in 
rats. These alterations might be responsible for the deficient transfer of folates to the fetus by the FABP. PY is also known to cross the placenta and accumulate in the embryo (Labbé et al, 1988).

Considering the concentration of folates in the embryonic bodies, statistical analysis indicates that a slight difference exists between the 4 treated groups. This difference could be attributable to the liver differentiation, which takes place between the 10 th and 11 th days of gestation. The principal site of embryonic DHFR synthesis is of hepatic origin and maximum enzyme activity is observed in 11-day-old embryos. At that time DHFR is very sensitive to $P Y$ action: its affinity for the drug is much higher at gestation days 11 and 12 than later (Repin et al, 1972).

These results confirm previous findings (Raynaud et al, 1990). However, we could not find any direct correlation between the decrease of folic acid which occurred with the lowest dose $(12.5 \mathrm{mg} / \mathrm{kg})$ and the congenital malformations first observed with a higher dose $(18.75 \mathrm{mg} / \mathrm{kg})$. Which factor could be responsible for the shifting between these 2 results? First, folic acid assay method could be involved. Folic acid is assayed as mono- and oligoglutamates after hydrolysis by endogenous conjugase. Biologically active conjugates are polyglutamates and the technique does not take into account active forms nor their cell availability. Secondly, the 2 lowest doses (12.5 and $15.63 \mathrm{mg} / \mathrm{kg}$ ) administered had no effect on organogenesis because the threshold of teratogenic sensitivity might occur with higher doses.

\section{ACKNOWLEDGMENTS}

We would like to thank G Potier de Courcy for the supply of the strain of Lactobacillus, S Bouvet for introduction to the assay method and G Coutris and A Solari for their help in the statistical analy- sis. Pyrimethamine was a gift of Rhône-Poulenc Specia.

\section{REFERENCES}

Baird CDC, Nelson MM, Monie IW, Evans HM (1954) Congenital cardiovascular anomalies induced by pteroylglutamic acid deficiency during gestation in the rat. Circ Res 2, 544-554

Bird OD, McGlohon VM, Vaitkus JW (1965) Naturally occurring folates in blood and liver of the rat. Anal Biochem 12, 18-35

Chambers JM, Cleveland WS, Kleiner B, Tukey PA (1983) Studying two dimensional data. In: Graphical methods for data analysis, Wadsworth and Brooks, Cole Publishing Company Advanced Brooks and Software Pacific Grove, CA, USA, 75-127

Christidès JP, Potier de Courcy G (1987) Teneur en acide folique des aliments. 2 . Optimisation du dosage microbiologique des folates dans les aliments. Science des Aliments 7, 7-22

Compagnon A (1987) Étude des malformations induites par la pyriméthamine chez le rat. Anomalies de la région faciale. Thèse Sciences (Paris)

Dyban AP, Barilyak IR, Tichodeeva II, Chebotar NA (1976) On correlation of teratogenic and antimitotic activity of some derivatives of 2,4-diaminopyrimidine. Ontogenez 7, 53-63

Green T, Ford HC (1984) Human placental microvilli contain high-affinity binding sites for folate. Biochem J218, 75-80

Hanson JW, Smith DW (1975) The fetal hydantoin syndrome. J Ped 87, 285-290

Hill RM, Verniaud WM, Horning MG, McCulley LB, Morgan NF (1974) Infants exposed in utero to antiepileptic drugs. Am J Dis Child 127, 645-653

Horvàth $\mathrm{C}$, Tangapregassom AM, Tangapregassom MJ et al (1989) Pathogenesis of limb and facial malformations induced by pyrimethamine in the rat. Acta Morph Hung 36, 53-61

Johnson EM, Nelson MM, Monie IW (1963) Effects of transitory pteroylglutamic acid (PGA) deficiency on embryonic and placental development in the rat. Anat Rec 146, 215-224

Jordan RL, Wilson JG, Schumacher HJ (1977) Embryotoxicity of the folate antagonist methotrexate in rats and rabbits. Teratology 15, 73-80

Khera SK (1992) Valproic acid-induced placental and teratogenic effects in rats. Teratology 45, 603-610

Labbé S, Boucher M, Dang Vu B, Tangapregassom AM, Barbet JP (1988) Does pyrimethamine cross the rat placenta? Quad di Anat Prat 44, 219A

Landon MJ, Eyre DH, Hytten FE (1975) Transfer of folate to the fetus. Br J Obstet Gynœecol 82, 12-19 
Laurence KM, James N, Miller M, Campbell H (1980) Increased risk of recurrence of neural tube defects to mothers on poor diets and possible benefits of dietary counselling. Br Med $J$ 281, 1542-1544

Milunski A, Græf JW, Gaynor MF (1968) Methotrexateinduced congenital malformations. J Ped 72, 790-795

Monie IW, Nelson MM, Evans HM (1954) Abnormalities of the urinary system of rat embryos resulting from maternal pteroylglutamic acid deficiency. Anat Rec 120, 119-135

Monie IW, Nelson MM, Evans HM (1957) Abnormalities of the urinary system of rat embryos resulting from transitory deficiency of pteroylglutamic acid during gestation. Anat Rec 127, 711-724

Peters PWJ (1977) Double staining of fetal skeletons for cartilage and bone. In: Methods in Prenatal Toxicology (R Neubert, HG Merker, TEK Kwasigroch, eds) Georg Thieme, Stuttgart, Germany 153-154

Potier de Courcy G, Bertaux O (1972) Analyse des folates dans les fœtus des rats témoins et carencés en acide folique. J Physio/ 65 suppl 3, 480A

Potier de Courcy G, Bujoli J (1981) Effects of diets with or without folic acid, with or without methionine, on fetus development, folate stores and folic acid-dependent enzyme activities in the rat. Biol Neonate $39,132-140$

Powell HR, Ekert H (1971) Methotrexate-induced congenital malformations. Med J Aust 2, 1076-1077

Raynaud F, Tangapregassom AM, Petter C (1990) Effet de la pyriméthamine à différentes périodes de gestation chez la ratte sur la teneur en folates maternels et fœtaux. Colloque INSERM 197, 419-428

Repin VS, Geiro ND, Rostovtsev VN, Vaisman BL (1972) Activity of 'early' and 'late' dehydrofolate reductase in induced abnormalities of mammalian embryogenesis. Ontogenez 3, 69-77

Sweiry JH, Yudilevitch DL (1985) Transport of folates at maternal and fetal sides of the placenta: lack of inhibition by methotrexate. Biochim Biophys Acta $821,497-501$

Sullivan FM, McElhatton PR (1977) A comparison of the teratogenic activity of the antiepileptic drugs carbamazepine, clonazepam, ethosuximide, phenobarbital, phenytoin, and primidone in mice. Toxicol Appl Pharmacol 40, 365-378

Tangapregassom AM, Tangapregassom MJ, Horvàth $C$, Trecul $M$, Boucher-Ehrensperger M, Petter $C$ (1985) Vascular anomalies and pyrimethamineinduced malformations in the rat. Teratogen Carcinogen Mutagen 5, 55-62

Thiersch JB (1952) Therapeutic abortions with folic acid antagonist 4-amino-pteroylglutamic acid (4-amino PGA) administered by oral route. Am J Obst Gynecol 63, 1298-1304

Thiersch JB, Philips FS (1950) Effect of 4-aminopteroylglutamic acid (aminopterin) on early pregnancy. Proc Soc Exp Biol Med 74, 204-208

Warkany $J$ (1978) Aminopterin and methotrexate: folic acid deficiency. Teratology 17, 353-358

Wilson JG (1965) Embryological consideration in teratology. In: Teratology: Principles and Techniques (JG Wilson, J Warkany, eds), University of Chicago Press, Chicago, USA, 251-277

Wilson JG, Scott WJ, Ritter EJ, Fradkin R (1979) Comparative distribution and embryotoxicity of methotrexate in pregnant rats and rhesus monkeys. Teratology $19,71-80$ 